\title{
Aprendendo a Química do Vinho
}

\author{
JO ÃO PEDRO ALPUIM *
}

Faz-se aqui uma travessia pela química do vinho em que se abordam alguns dos seus aspectos mais importantes do ponto de vista enológico. Os diferentes compostos que constituem o vinho e a sua química são, por isso, discutidos na medida em sejam responsáveis ou concorram para determinada propriedade organoléptica**. Assim, depois de uma passagem rápida pelos processos biotecnológicos da fermentação, descrevem-se, sucinta e sucessivamente, os processos e as substãncias do paladar doce, do paladar ácido, onde se discutem os conceitos enológicos de acidez e se compara com o de $\mathrm{pH}$, e do paladar salgado; seguem-se os compostos e os processos da cor, as substâncias da nutrição e, finalmente, o problema do aroma, e alguns compostos com ele relacionados são abordados.

\section{APRESENTAÇÃO}

O vinho é uma bebida muito antiga. Era já um hábito alimentar entre os sicilianos, no ano 2000 a.C.. Os egípcios conheceram-no e beberam-no muito cedo. Na Ilíada e na Odisseia, Homero refere-se sempre ao vinho nos banquetes dos seus heróis. Os romanos iriam transportar consigo a técnica da cultura da vinha durante a expansão do seu império.

No século III d.C. as zonas vinhateiras da Europa eram já, sensivelmente, as mesmas de hoje.

O vinho existe, portanto, há muito mais tempo do que a química e do que a ciência moderna. Ele é, no entanto, um produto quimicamente complexo! É, também, um produto natural e como tal deve ser bebido.

A definição enológica' ${ }^{1}$ e legal do vinho diz-nos que é o produto obtido exclusivamente pela fermentação alcoólica, total ou parcial, de uvas frescas ou do mosto de uvas frescas. Não é, em todo o caso, menos verdade e disso se ocupa a enologia - que. sem a intervenção humana, a natureza não nos deixaria pinga de vinho intacto, pois, mais ou menos rapidamente, todo o vinho evolui naturalmente para vinagre.

Assim, desde que o homem colhe uvas e as esmaga, ou as deixa fermentar inteiras, com o objectivo de obter vinho, tem-se visto a braços com a dificuldade, e esta não é pequena, de o conservar para beber, ou, pior ainda, transportar para ser bebido por outros, noutros locais.

A compreensão racional do processo da conservação do vinho só o desenvolvimento da química e da microbiologia puderam permitir. De facto, quando hoje sabemos que existem no vinho mais de 600 compostos químicos diferentes, incluindo todas as funções mais importantes da química orgânica, quando nos apercebemos da variedade microbiológica eventualmente existente num tonel de vinho, não podemos deixar de sorrir perante as dificuldades encontradas pelos nossos antepassados romanos e outros, muito mais recentemente, ao tentarem conservar com saúde as suas ânforas, pipas, almudes ou garrafas contendo o precioso produto das suas colheitas.

A química do vinho é, assim, qualquer coisa de complexo que ainda hoje não é totalmente conhecida, embora as modernas e poderosas técnicas espectroscópicas e cromatográficas, por exemplo, tenham permitido em anos recentes avanços gigantescos na compreensão dos processos naturais que se produzem no interior do vinho (no princípio deste século, apenas se conheciam pouco mais de meia dúzia de substâncias como constituintes do vinho; há 40 anos, cerca de 50; hoje, mais de 600).

$\mathrm{Na}$ determinação das características químicas de um vinho estão sobretudo envolvidas a Química Analítica e a Química-Física. Isto porque o vinho é uma solução e, assim, a sua química é determinada não só pela sua composição analítica, mas também pelo jogo dos equilíbrios químico-físicos envolvidos, equilíbrios ácido-base, equilíbrios de oxidaçãoredução, de solubilidade, etc.
Um outro aspecto importante na análise do vinho cujos progressos recentes têm sido muito importantes é o do estabelecimento de correlações entre as propriedades organolépticas do vinho, ou seja, as características perceptíveis pelos nossos sentidos 2 e que justamente the conferem o título de bebida mais nobre entre todas - e o seu fundamento químico-físico. Será tendo em conta este último critério que iremos tratar, em traços gerais, da composição do vinho neste trabalho.

É ainda apenas através da análise química que é possível detectar a maior parte das fraudes no fabrico do vinho. Embora não seja esse o tema que nos ocupa aqui, importa, no entanto, salientar que, conquanto a classificação de fraudulentos duma grande parte dos processos que o são, não ofereça dúvidas e seja perfeitamente clara e definitiva - trata-se de falsificações - outros casos há em que a fronteira não é tão nítida e a classificação de um processo como fraudulento pode variar mesmo de país para país.

Por exemplo, enquanto que em Portugal é proibido o enriquecimento do mosto - seja sob a forma de adição de sacarose ou de mosto concentrado - com vista ao enriquecimento alcoólico do produto final, noutros países mais setentrionais ${ }^{3}$ essas técnicas são geralmente aceites e, até, imprescindíveis. Foi um químico francês do século passado. Chaptal, quem a descobriu e lhe concedeu a importância que tem nessas regiões de clima mais frio e pouco soalheiro onde é autorizada.

Noutros casos, a fronteira entre o legal e o fraudulento situa-se ao nível da concentração em determinado composto, apresentada pelo vinho. Está neste caso o teor em metanol; está neste caso ainda o teor em dióxido de enxofre, adicionado como conservante, ainda hoje insubstituível no conjunto das técnicas de estabilização e conservação de qualquer tipo de vinho.

Os teores máximos autorizados em $\mathrm{SO}_{2}$ livre (gasoso) dissolvido no vinho, variam entre os 70 e os 100 
mg/l, conforme os tipos de vinho. Acima destas concentrações, o emprego do dióxido de enxofre é proibido.

A título de curiosidade, consta que foi de uma tentativa de estabilização dos vinhos do Douro exportados e muito apreciados em Inglaterra, mas muitas vezes deteriorados durante o transporte, que surgiu o Vinho do Porto. A ideia era conservar os vinhos por adição de uma grande quantidade de álcool vínico (aguardente) tornando o produto mais estável. A graduação alcoólica habitual seria mais tarde recuperada. Sucedeu, no entanto, que os vinhos enriquecidos com aguardente se tornaram mais apreciados ainda pelos ingleses do que os próprios vinhos de base, originando assim a grande procura e comércio do hoje famoso Vinho do Porto.

Seguidamente referir-nos-emos aos constituintes químicos do vinho, agrupando-os segundo o critério acima referido e que consiste em considerá-los na perspectiva da sua contribuição para os factores organolépticos. Em muitos casos há uma correspondência exacta e estrita entre as características sensoriais do vinho e os compostos químicos que lhes dão origem. Outras vezes, um mesmo composto ou família de compostos influi sobre aspectos diversos e totalmente distintos do ponto de vista da análise sensorial.

Sucede ainda que uma determinada característica organoléptica de um vinho é frequentemente o resultado da combinação particular de uma certa composição química e aquilo que impressiona os nossos sentidos é o resultado não de uma, mas de um conjunto de moléculas químicas que simultaneamente concorrem para o efeito observado.

Permita-se-nos, ainda, relembrar que este não é um trabalho exaustivo sobre a constituição química do vinho e que, por outro lado, a lista final dos seus constituintes não se encontra tão pouco concluída.

Assim, faremos referência apenas a alguns daqueles cerca de 600 compostos actualmente já identifica- dos, entre os quais se contam perto de 200 ésteres, 140 ácidos, 50 alcoóis e compostos de carbonilo, cerca de 30 compostos azotados, 20 acetais, lactonas, fenóis e compostos sulfurados e ainda 10 furanos e epóxidos.

\section{A BIOTECNOLOGIA}

O vinho é o produto da fermentação alcoólica do sumo de uvas frescas. A fermentação alcoólica é o processo microbiológico através do qual seres vivos unicelulares - as leveduras - obtêm a sua energia vital. A fermentação é apenas um dos processos que pode fornecer energia aos micro-organismos. O outro é a respiração, mais rentável em termos energéticos, mas que se dá apenas na presença e com a utilização do oxigénio do ar. À respiração anaeróbia (sem ar) chama-se fermentação; como coloca menos energia à disposição das células dos micro-organismos, estes têm de aproveitar toda a "matéria prima" ao seu dispôr. No caso da fermentação alcoólica, as leveduras transformam todo o açúcar disponível em álcool. Os açúcares fermentáveis existentes no mosto são a glucose e a frutose. O álcool produzido pelas leveduras é o etanol.

A glucose é uma aldo-hexose (cadeia em C-6) e a frutose é uma ceto-hexose (fig.1).

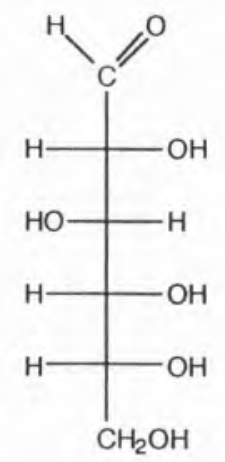

(A)

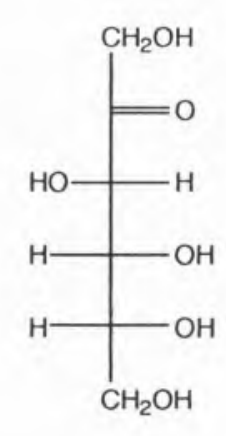

(B)
Fig. 1 - Glucose (A) e frutose (B) são os principais açúcares da uva. A glucose é uma aldohexose e a frutose é uma cetohexose.
Existem também pentoses no mosto das uvas, sob formas combinadas, que são libertadas durante a fermentação. No entanto, as pentoses não são fermentadas pelas leveduras. Glucose e frutose formam o dissacárido sacarose (fig.2).

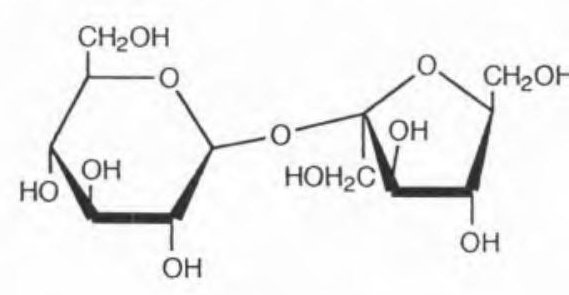

Fig. 2 - A sacarose é o diósido não redutor de
glucose e frutose.
A glucose está na forma $\alpha$-piranose e a frutose,
na forma $\beta$-furanose. A sacarose é, por isso,
1- $\alpha$-D-glucopiranosil- $\beta$-D-frutofuranósido.

Os açúcares são produtos da fotossíntese nas folhas da videira e existem como alimento de reserva no material lenhoso da planta. A sacarose é, no entanto, hidrolisada a glucose e frutose e o amido em glucose, sendo estes dois monossacáridos que migram para o bago de uva onde são armazenados ao longo da maturação. Ambos são da série D, na videira e no mosto. Existem nas formas piranose (anel de 6 membros) e furanose (anel de 5 membros), e, em solução, formam uma mistura dos isómeros $\alpha$ e $\beta$ (figs.3 e 4).

Na uva verde há mais D-glucose do que D-frutose. Contudo, ao longo da maturação a relação GLU/FRU diminui e, na uva madura de casta europeia, a razão $\mathrm{G} / \mathrm{F}$ é de 0,95 . As leveduras vão, ainda, fermentar muito mais rapidamente a glucose do que a frutose, de forma que a relação baixa sempre até ao fim da fermentação. Por isso, nos vinhos com fermentação interrompida ou nos traços de açúcares redutores por fermentar dos vinhos $\operatorname{secos}^{4}$ a razão GLU/FRU é muito pequena. Esta constitui, aliás, a forma de detectar se o mosto foi enriquecido por adição de sacarose.

A transformação dos açúcares redutores em etanol faz-se através de uma complexa série de mais de 30 reacções químicas sucessivas, 
cada uma das quais é catalizada por um enzima específico, fazendo parte da ferramenta biológica das leveduras. Cada uma destas reacções vai produzindo também produtos secundários que depois se vão encontrar no vinho em maior ou menor concentração (sempre muito baixa, em comparação com o etanol). Alguns destes são a glicerina, os ácidos succínico, acético, láctico e pirúvico, o acetaldeído, polialcoóis e um grande número de outras substâncias presentes em quantidades muito pequenas. A fermentação produz. ainda $\mathrm{CO}_{2}$ que se liberta sob a forma de gás, ficando ainda assim uma pequena parte dissolvida no vinho. Foi Lavoisier quem mostrou que o açúcar se tranformava em álcool e dióxido de carbono e foi a propósito da fermentação que ele formulou o célebre princípio da química de que na natureza tudo se transforma. Gay-Lussac procurou depois quantificar a relação açúcar, álcool e dióxido de carbono, mas foi Pasteur quem se apercebeu que apenas cerca de $90 \%$ do açúcar dava álcool e $\mathrm{CO}_{2}$, o resto originando todos os outros produtos secundários. A fermentação alcoólica pode ou não ser seguida, no vinho, da fermentação maloláctica do ácido málico pelas bactérias lácticas. Esta fermentação, que se dá espontâneamente se o vinho for suficientemente rico em ácido málico (uvas não excessivamente maduras), tiver pH favorável (4-5) e concentração suficiente de aminoácidos e vitaminas necessárias ao desenvolvimento das bactérias lácticas, consiste numa transformação do ácido málico em ácido láctico com libertação de dióxido de carbono e formação de uma pequena quantidade de ácido acético, entre outros produtos.

O principal interesse desta fermentação, praticada sempre nos vinhos tintos que se destinam a envelhecer bem como em certos vinhos jovens de elevada acidez, reside no abaixamento da acidez titulável e no aumento do $\mathrm{pH}$, visto que o ácido láctico é mais fraco do que o ácido málico 5 . Alguns dos estudos e avanços mais importantes na biotecnologia do vinho residem actualmente no estudo desta fermentação e na preparação e venda de culturas das espécies de bactérias lácticas mais favoráveis, sobretudo em termos do controlo da formação de produtos secundários. Existem vários tipos de bactérias lácticas (bacilos e cocos) no vinho e as condições óptimas de cultura variam com as espécies, o que também constitui factor de escolha, de acordo com a composição do vinho cuja fermentação se pretende.

\section{OS COMPOSTOS QUÍMICOS DO VINHO}

\subsection{As substâncias do paladar doce}

O etanol é, depois da água, o constituinte maioritário do vinho: nos vinhos de mesa o seu teor varia entre $8,5 \%$ e $14 \%$ em volume, e é superior a $17 \%$ nos vinhos generosos. Ele determina, juntamente com a água, as características do meio ${ }^{6}$. As constantes de ionização dos ácidos têm valores diferentes no etanol e assim, o pH do meio é influenciado pela presença deste. O sabor do etanol, aliás como o de muitas outras substâncias cujas moléculas contêm muitos grupos $\mathrm{OH}$ como função principal, é adocicado e relativamente macio na boca. Como se disse, ele é de longe o principal produto da fermentação alcoólica (cerca de $90 \%$ ) dos açúcares do mosto.

O teor em etanol de um vinho é função do estado de maturação das uvas que lhe deram origem e, portanto, da sua riqueza em açúcares fermentáveis. O teor em etanol está, também, estreitamente associado à qualidade do vinho, embora não seja o único factor desta. Mas uma concentração em etanol suficientemente alta indica um ano de boa maturação, com todos os fenómenos favoráveis que the estão associados. Por outro lado, nem todas as variedades de videiras nem de solos são capazes

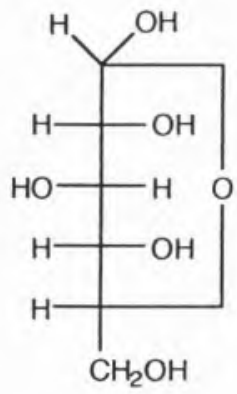

(A)

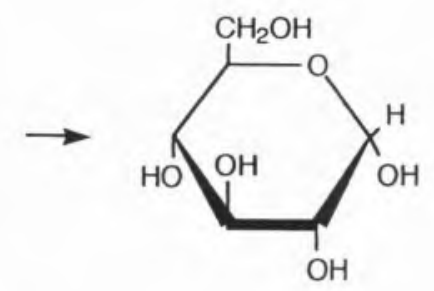

(B)
Fig. 3 - Estrutura cíclica da glucose,

$\alpha$-D-glucopiranose.

Representações de Tollens (A) e de Haworth (B).

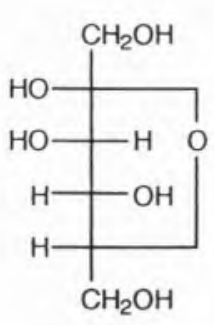

(C)

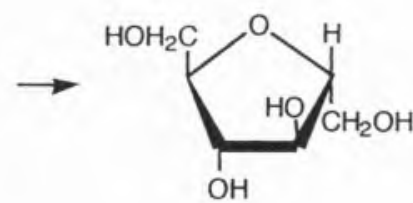

(D)
Fig. 4 - Estrutura cíclica da frutose, $\beta$-D-frutofuranose.

Representações de Tollens (C) e de Haworth (D)

de produzir mostos suficientemente açucarados, mesmo em anos favoráveis, o que quase sempre é um indicador de falta de aptidão para produzir vinhos de qualidade.

O terceiro composto em abundância no vinho é o glicerol (fig.5), que se forma durante a fermentação alcoólica. A sua concentração no vinho varia entre 6 e $15 \mathrm{~g} \cdot \mathrm{l}^{-1}$. É também um factor de qualidade porque confere macieza ao vinho e porque atesta uma fermentação bem conduzida (temperatura, acidez, arejamento, sulfitação ${ }^{7}$ ).

É interessante o facto de as uvas podres conduzirem a um enriquecimento em glicerol. Isto deve-se ao facto de o fungo da podridão, botrytis cinerea, produzir glicerol a partir dos açúcares do mosto.

Os outros compostos que contribuem para o paladar doce são, naturalmente, os açúcares e, também, os polióis deles derivados (fig.5). 
<smiles>OCC(O)C(O)C(O)CO</smiles>

arabitol

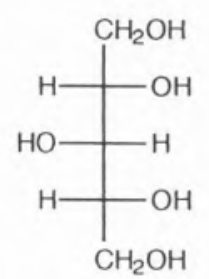

xilito
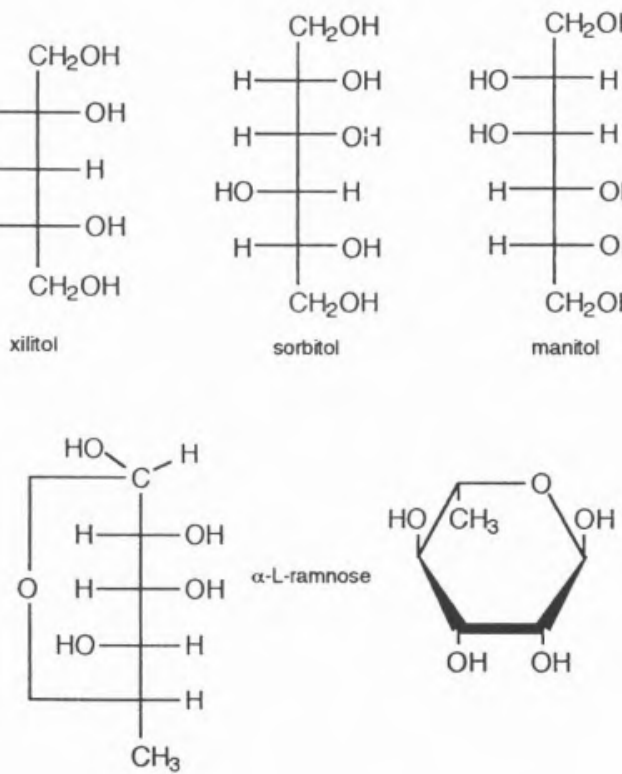

Glicerol<smiles>O=CC(O)C(O)C(O)CO</smiles>

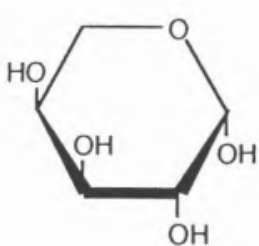

$\alpha$-L-arabinose

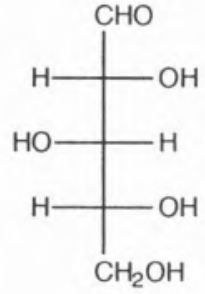

D-xilose

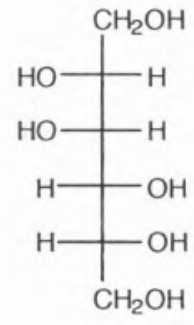

manitol
D-arabinose bstâncias do paladar doce.

Fig. 5 - As moléculas das substâncias do paladar doce.

Os açúcares são os residuais da fermentação (glucose e frutose) e as pentoses não fermentáveis entre as quais se contam a arabinose, a ramnose e a xilose (fig.5). Uma pequena parte das duas primeiras bem como um pouco de glucose pode resultar da hidrólise enzimática (pelas glicosidases da uva) ou química de heterósidos polifenólicos ou terpénicos. De todos os açúcares a glucose é o que tem maior poder edulcorante (mais do que a sacarose).

Os polióis derivam das hexoses e das pentoses, encontrando-se no vinho sorbitol e manitol, provenientes das primeiras, e arabinol, xilitol e adositol, com origem nas segundas. O manitol pode aparecer em maiores concentrações em vinhos doentes, em que alguma frutose tenha sido fermentada por bactérias lácticas heterofermentárias.

\subsection{As substâncias do paladar ácido}

Em enologia, nenhum dos três conceitos de acidez habitualmente usados - acidez fixa, acidez volátil e acidez total - corresponde ao $\mathrm{pH}$. No entanto, é o pH que controla muitos dos processos químicos que têm influência nas características sensoriais do vinho. Por isso, o conhecimento e o controlo do $\mathrm{pH}$ do vinho tornam-se cada vez mais importantes para o enólogo. De facto, é este o único conceito que descreve a acidez real, efectiva, correspondente à concentração do ião $\mathrm{H}^{+}$em solução.

\subsubsection{O pH do vinho.}

$\mathrm{O}$ vinho tem $\mathrm{pH}$ ácido, variando entre cerca de 2,8 e 3,8 . Ou seja, a concentração $\left[\mathrm{H}^{+}\right]$pode variar numa proporção de 1 para 10. Além disso, no mesmo vinho, o $\mathrm{pH}$ varia ao longo da fermentação e, depois, durante a conservação.

Citaremos alguns fenómenos muito importantes em enologia e que dependem do $\mathrm{pH}$ :

(i) O sabor que apresentam os ácidos do vinho depende do $\mathrm{pH}$ (mas não só, como veremos). Por outro lado, uma concentração elevada de iões $\mathrm{H}^{+}$transmite ao vinho um paladar "magro" (delgado) e seco.

(ii) As diversas bactérias não conseguem atacar os constituintes do vinho que lhe são específicos se o pH for demasiado baixo. Mesmo que seja suficientemente alto, o resultado do ataque é diferente, consoante o $\mathrm{pH}$.

Por exemplo, a pior doença que pode acontecer a um vinho, a "volta", que é a decomposição do ácido tartárico pelas bactérias, só ocorre a pH superior a 3,5. A fermentação maloláctica - de grande importância, como se referiu - embora ocorra a todos os valores de $\mathrm{pH}$, é, no entanto, facilitada por um valor mais alto de $\mathrm{pH}$.

(iii) As casses férricas e cúpricas, que são precipitações de compostos ou de complexos insolúveis de ferro III e cobre II, ocorrem a um pH óptimo entre 3,0 e 3,5 .

(iv) As precipitações de bitartarato de potássio (sarro) que são um dos acidentes mais vulgares, sem gravidade, que ocorrem com qualquer vinho, têm um $\mathrm{pH}$ de probabilidade máxima de ocorrência a cerca de 3,6 .

(v) Por arejamento, o sulfito utilizado como conservante e antioxidante no vinho, é oxidado a sulfato, o que baixa o $\mathrm{pH}$ do vinho por ser o anião de um ácido forte, levando-o a "secar". Este termo é usado para traduzir a sensação gustativa que ocorre quando se prova um vinho com pH muito baixo. É por isto que os vinhos brancos não podem conservar-se em cascos de madeira (onde a oxidação se dá a um ritmo acelerado).

(vi) O poder anti-séptico e o cheiro que o dióxido de enxofre confere ao vinho aumentam muito com 
a concentração em iões $\mathrm{H}^{+}$, visto que a fracção não dissociada de $\mathrm{SO}_{2}$ dissolvido é maior.

\subsubsection{Acidez fixa, volátil e total}

Em enologia, a acidez total corresponde à acidez titulável; dá, portanto, informação sobre a concentração analítica da totalidade dos ácidos presentes no vinho, dissociados ou não.

Como a maior parte dos ácidos do vinho são ácidos orgânicos e, por isso, relativamente fracos, eles encontram-se em equilíbrio com as suas bases conjugadas numa extensão dada pelos respectivos $\mathrm{pK}_{\mathrm{a}}$. Devido à presença de catiões metálicos e de $\mathrm{NH}_{4}{ }^{+}$, eles podem precipitar sob a forma de sais numa extensão controlada agora pelos respectivos $\mathrm{K}_{\mathrm{ps}}$. A fracção que se encontra na forma de sal não contribui para a acidez total.

O enólogo considera ainda a acidez total como a soma da acidez fixa e da acidez volátil. A primeira, é constituída pelos ácidos orgânicos não voláteis, não ionizados, presentes no vinho. A segunda, pelos ácidos voláteis obtidos por destilação directa ou por corrente de vapor.

Os principais ácidos que contribuem para a acidez fixa são os ácidos orgânicos originários da uva e da(s) fermentação(ões). Os ácidos inorgânicos, existentes em pequena quantidade, estão totalmente na forma de sais ao $\mathrm{pH}$ do vinho e contribuem, assim, para o paladar salgado, não tendo paladar ácido.

Os ácidos voláteis são o ácido acético e os ácidos carboxílicos alifáticos da série acética. Todos eles possuem um aroma rançoso e picante (ácidos fórmico, propiónico, butírico, etc.).

O teor em ácido acético no vinho dá-nos uma indicação sobre o seu "estado de saúde" actual e sobre as doenças que teve no passado. De facto, forma-se sempre algum ácido acético durante as fermentações alcoólica e maloláctica, caso esta se tenha dado. No entanto estes teores são pequenos, da ordem dos 0,2 a $0,3 \mathrm{~g} \cdot \mathrm{l}^{-1}\left(0,4 \mathrm{~g} \cdot \mathrm{l}^{-1}\right.$ se tiver havido maloláctica). Teores superiores a estes, sobretudo em vinho jovens, testemunham acidentes na fermentação alcoólica ou ataques bacterianos. Estes resultam das bactérias acéticas que, em aerobiose - quando o vinho fica exposto ao ar - oxidam o etanol a ácido acético. Este processo químico conduz também à formação de acetato de etilo, indesejável pelo cheiro desagradável e sabor picante que traz ao vinho.

As bactérias lácticas heterofermentárias são também susceptíveis de atacar, na ausência de ar, diversos outros constituintes do vinho, com formação de ácido acético.

Estes conceitos enológicos de acidez são um tanto formais do ponto de vista químico, no entanto, eles são úteis na análise do vinho e na dedução de critérios de qualidade de vinificação e de controlo da conservação e do envelhecimento. Quando, por exemplo, se produz aguardente por destilação do vinho, toda a acidez volátil passa ao destilado enquanto os ácidos da acidez fixa ficam no resíduo,

Os teores máximos de acidez volátil são regulamentados por lei, para defesa do consumidor. Em Portugal, a acidez volátil não pode ser superior a $1,2 \mathrm{~g} \cdot \mathrm{I}^{-1}$ expressa em ácido acético.
A acidez fixa é um dos critérios para distinguir vinhos produzidos em diferentes regiões vinícolas e, por esse motivo, também ela é regulamentada nos D.O.C. ${ }^{8}$.

A relação entre acidez fixa e teor em etanol influi decisivamente na sensação de conjunto que o vinho produz na boca do provador, e muitos outros exemplos seriam possíveis que ilustram a utilidade de tais conceitos de acidez na prática quotidiana do enólogo.

O emprego generalizado do $\mathrm{SO}_{2}$, como conservante, bem como a dissolução do $\mathrm{CO}_{2}$ originário das fermentações, conduz a um ligeiro aumento da acidez total e volátil, por formação dos ácidos sulfuroso e carbónico. Estes teores devem ser determinados e descontados quando se faz a determinação da acidez.

Os ácidos da acidez fixa têm origem na uva ou são produtos da fermentação. Os mais importantes são, no primeiro caso, os ácidos tartárico, málico e cítrico; no segundo caso, os ácidos láctico e succínico. Os outros ácidos existentes no vinho têm concentrações muito baixas $\left(<0,1 \mathrm{~g} \cdot \mathrm{l}^{-1}\right)$ com excepção dos ácidos urónicos derivados dos açúcares, alguns dos quais podem aparecer em quantida-

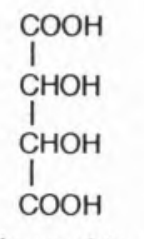

ácido tartárico

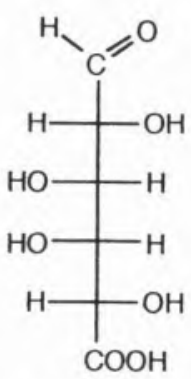

ácido galacturónico

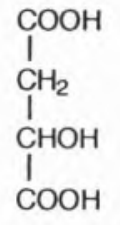

ácido málico

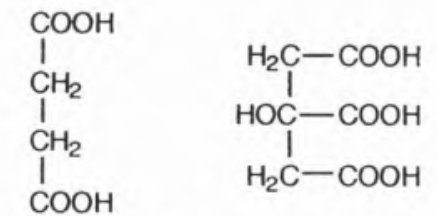

ácido cítrico

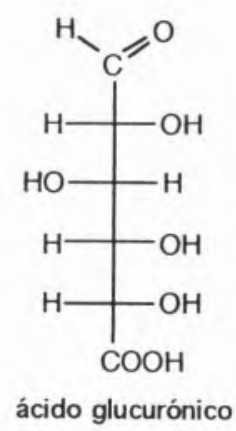

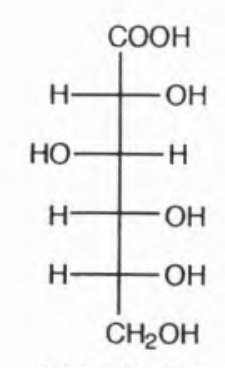

ácido glucónico

Fig. 6 - Alguns ácidos do vinho. 
des superiores a $2 \mathrm{~g} \cdot \mathrm{l}^{-1}$ (ácidos galacturónico, glucónico, tetrahidroxiadípico e glucurónico) (fig.6).

Os fenóis e compostos fenólicos, ácidos, são responsáveis no vinho não pelo sabor ácido, mas pelo sabor adstringente e amargo. Serão tratados à parte.

\subsubsection{Os principais ácidos do vinho.}

\section{O ácido tartárico}

É o principal ácido do vinho (2 a $\left.5 \mathrm{~g} \cdot \mathrm{l}^{-1}\right)$. É também o ácido específico da uva e do vinho. A não ser aqui, encontra-se muito pouco na natureza.

Dos cinco ácidos que citaremos é o mais resistente ao ataque pelas bactérias e é também o mais forte. É, além disso, o único que põe problemas na estabilização do vinho por causa dos seus sais pouco solúveis? Com efeito, o enriquecimento em álcool do vinho em relação ao mosto, diminui a solubilidade dos tartaratos (de cálcio, sobretudo) e bitartaratos (de potássio), ocorrendo precipitações por vezes quando menos se desejaria (quando se põe uma garrafa de vinho no frigorífico, por exemplo). O uso de linhas de frio e técnicas de centrifugação e filtração tem-se mostrado eficaz na solução deste problema. Muito útil é também o emprego do ácido metatartárico que se adiciona antes do engarrafamento e que actua como um colóide protector: ele liga-se aos centros de nucleação dos cristais de bitartarato, envolvendo-os e impedindo o seu posterior crescimento, inibindo a precipitação.

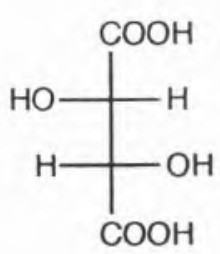

D (-)

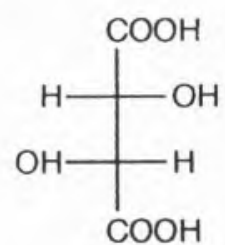

L (+)
Fig. 7 - Isómeros do ácido tartárico: apenas a forma D existe na uva
Em certos casos de insuficiência de acidez, a lei autoriza a adição de ácido tartárico. A terrível doença da volta, hoje totalmente erradicada se a vinificação for racionalmente conduzida, consiste na degradação do ácido tartárico nos ácidos acético e láctico ou acético e succínico, conforme o ataque provenha da bactéria lactobacillus plantarum ou da bactéria lactobacillus brevis.

\section{O ácido málico}

Abundante na uva verde, o ácido málico vai diminuindo ao longo da maturação até cerca de 1 a $8 \mathrm{~g} \cdot \mathrm{l}^{-1}$ no mosto. As leveduras degradam também uma pequena parte (entre $10 \mathrm{e}$ $25 \%$ do total) em ácido pirúvico, que entra depois no ciclo da fermentação alcoólica e dá etanol. Quando se pratica a fermentação maloláctica, ele é transformado pelas bactérias lácticas em ácido láctico L (+).

\section{O ácido láctico}

Não existe na uva. É formado pelas leveduras pela via do ácido pirúvico na fermentação alcoólica $(0,2$ a $0,4 \mathrm{~g} \cdot \mathrm{l}^{-1}$ ) ocorrendo em qualquer vinho, pelo menos nessas concentrações.

Nos vinhos submetidos à fermentação maloláctica, a concentração vem acrescida de 1 a $2,5 \mathrm{~g} \cdot \mathrm{l}^{-1}$. No entanto, outras reacções indesejáveis desencadeadas por ataque bacteriano podem ocorrer, também com formação de ácido láctico (por exemplo. no caso citado da volta do vinho).

Nestes casos - teores superiores a $3 \mathrm{~g} \cdot \mathrm{l}^{-1}$ - o vinho está estragado.

O ácido láctico formado pelas leveduras é sobretudo o enantiómetro D (-). Ao contrário, o L (+) é o único produzido pelas bactérias.

\section{O ácido succínico}

É um produto da fermentação alcoólica. Pode também formar-se a partir dos ácidos glutâmico e málico. Ao contrário dos anteriores, ele é muito estável aos ataques bacterianos. Além disso, o seu paladar não é verdadeiramente ácido, mas antes salino, amargo e intenso, provocando a salivação. É, de todos estes ácidos, o de sabor mais rico.
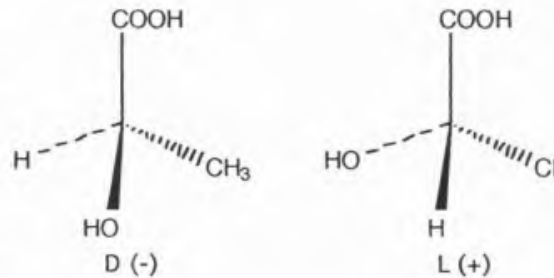

Fig. 8 - Enantiómetros do ácido láctico.

A deteç̧ão dos ácidos voláteis no vinho, ou dos ésteres seus derivados funcionais, tem prosseguido com rapidez crescente nos tempos mais recentes, sobretudo devido ao uso generalizado da cromatografia em fase gasosa na análise enológica. Conta-se hoje por algumas centenas o número desses compostos já detectados no vinho, alguns em muito pequenas concentração ou apenas vestígios.

\subsection{As substâncias do paladar salgado}

Como se disse, estas substâncias são os sais dos ácidos inorgânicos parcialmente ionizados. A sua determinação quantitativa faz-se pela identificação dos catiões metálicos encontrados nas cinzas do vinho. Estas, por sua vez, resultam da combustão do extracto seco, que é o que se obtém quando se evapora o vinho à secura.

Todas as substâncias minerais encontradas foram absorvidas pela videira (sobretudo do solo) e aquelas que se encontravam no bago da uva na altura da vindima passaram ao mosto e, depois, ao vinho.

Dos catiões presentes nas cinzas, como carbonatos e óxidos, o $\mathrm{K}^{+}$é de longe o mais abundante $(0,5$ a $2,0 \mathrm{~g} \cdot \mathrm{l} \cdot$ 1) seguido de $\mathrm{Ca}^{2}+\mathrm{e} \mathrm{Mg}^{2}+(50$ a 150 $\left.\mathrm{mg} \cdot \mathrm{l}^{-1}\right)$. O cálcio é mais abundante do que o magnésio, na uva. No entanto esta relação aparece invertida no vinho, devido à precipitação do tartarato de cálcio durante a conservação, sobretudo a baixa temperatura.

$\mathrm{O}$ sódio, $\mathrm{Na}^{+}$, existe no vinho em concentrações da ordem da dezena de $\mathrm{mg}$ por litro. Este valor pode subir no caso de vinhos provenientes de solos salgados. 
Os iões $\mathrm{Li}^{+}, \mathrm{Fe}^{3+}$ e $\mathrm{Cu}^{2+}$ podem aparecer em concentrações superiores ao $\mathrm{mg} / \mathrm{l}$. O teor do vinho em ferro e cobre depende muito do material utilizado na vindima, no esmagamento das uvas e na adega. Faltas de cuidado neste aspecto podem conduzir a problemas graves no vinho acabado: casses férrica e cúprica que são precipitações e alterações que ocorrem pela complexação de $\mathrm{Fe}^{3+} \mathrm{e} \mathrm{Cu}^{2+}$ com vários constituintes do vinho.

Todos os outros catiões presentes apresentam concentrações inferiores ao $\mathrm{mg} / \mathrm{l}$.

Os principais aniões inorgânicos, além do sulfito e bissulfito, carbonato e bicarbonato (originários do $\mathrm{SO}_{2}$ usado como conservante e da dissolução de $\mathrm{CO}_{2}$ formado na fermentação, respectivamente), são o fosfato, o sulfato e o cloreto.

A presença de fosfatos no mosto em concentrações da ordem dos 700 $\mathrm{mg} \cdot \mathrm{l}^{-1}$ é fundamental para o desenvolvimento da fermentação, em particular na glicólise que envolve diversos passos de fosforilação. No vinho, o teor em fosfatos varia de 20 a $160 \mathrm{mg} \cdot \mathrm{l}^{-1}$, para os brancos, e de 50 a $300 \mathrm{mg} \cdot \mathrm{l}^{-1}$, para os tintos.

Os sulfatos encontram-se em quantidades que vão de 150 a 300 $\mathrm{mg} \cdot \mathrm{l}^{-1}$. Estes valores podem aumentar em consequência da oxidação do sulfito a sulfato, durante a conservação.

A concentração em cloretos é da ordem dos $50 \mathrm{mg} \cdot \mathrm{l}^{-1}$, apenas. Do mesmo modo do que para o sódio, estes valores podem elevar-se para vinhos originários de solos salgados.

O silício e o boro fornecem também aniões, que se encontram no vinho em doses de 5 a $20 \mathrm{mg} \cdot \mathrm{l}^{-1}$. Outros elementos estão ainda presentes mas em concentrações inferiores ao $\mathrm{mg} \cdot \mathrm{l}^{-1}$.

\subsection{As substâncias da cor.}

A coloração apresentada pelos compostos químicos é devida a transições electrónicas quando absorvem radiação de comprimento de onda na região do visível. As transições electrónicas cuja diferença de ener-

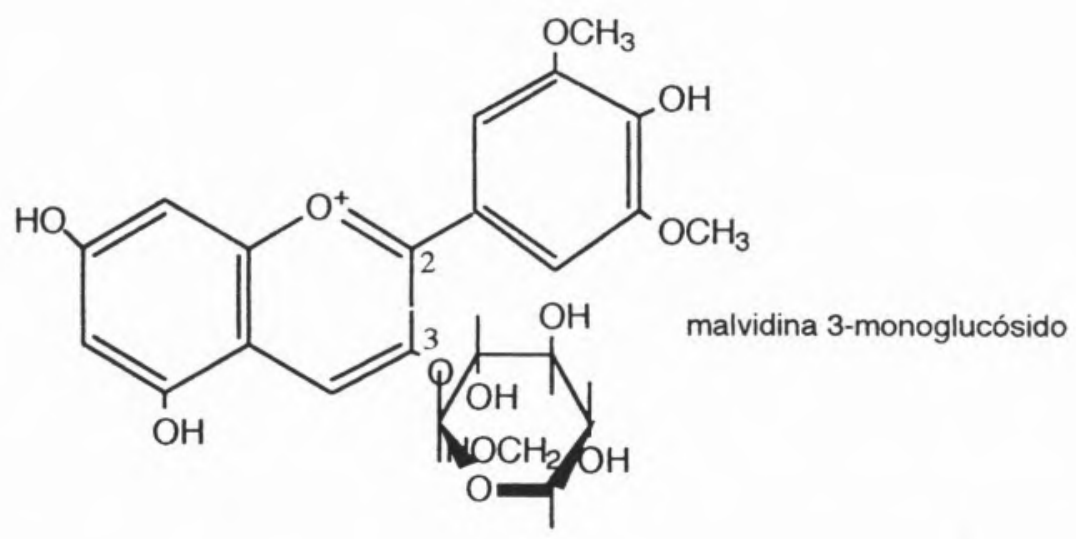

Fig. 9 - Antocianina monoglucósido.

gia corresponde a essas absorções são geralmente $\pi \rightarrow \pi^{*}$. As ligações duplas fornecem este tipo de orbitais moleculares; estas transições podem, também, dar-se entre orbitais atómicas de átomos contendo pares de electrões não ligantes $\left(\mathrm{n} \rightarrow \pi^{*}\right)$. Os compostos fenólicos e os polifenóis, que existem no vinho, são os responsáveis pela cor. Estes compostos possuem um ou vários anéis fenólicos substituídos com um ou mais grupos $\mathrm{OH}$ e, por vezes, outras funções (alcóxilo ou ácido, por exemplo).

Polimerizam com facilidade, originando moléculas com grandes cadeias de ligações duplas conjugadas que são, em muitos casos, determinantes na coloração que eles exibem. A grande importância que estes compostos têm no vinho não se es-

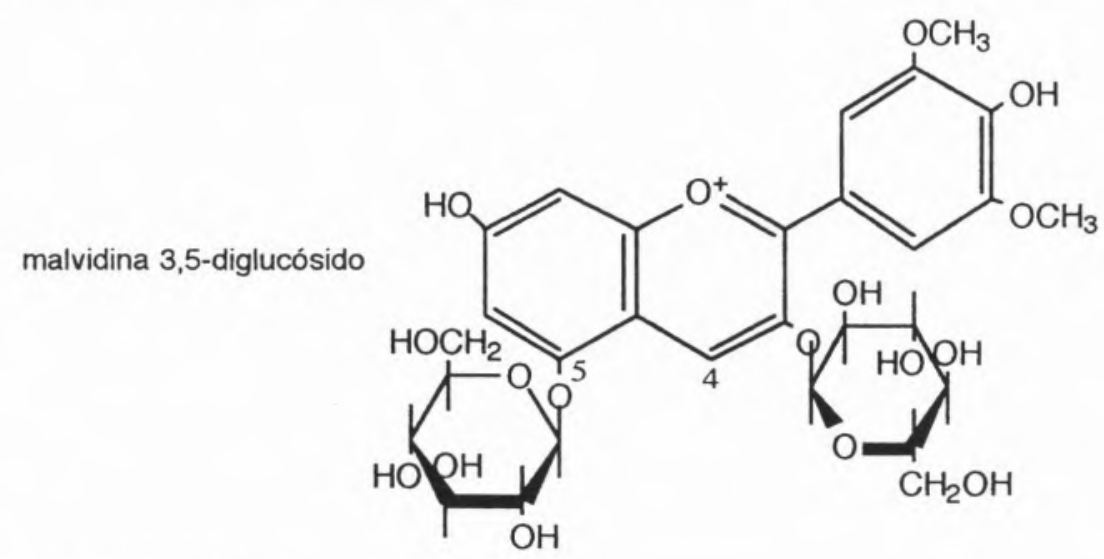

Fig. 10 - Antocianina diglucósido. gota, no entanto, nesta sua característica corante:

- influenciam de maneira determinante a percepção gustativa que temos de um vinho, conferindolhe a "estrutura" e o "corpo";

— têm acção bactericida e são constituintes da vitamina $\mathrm{P}$, contribuindo assim para a qualidade do vinho como nutriente;

- interferem de modo determinante no processo de envelhecimento do vinho, visto que a evolução da cor e do paladar com o decorrer do tempo se devem a reacções envolvendo os compostos fenólicos.

Infelizmente, e apesar dos progressos realizados nos últimos anos a partir do desenvolvimento de muitas técnicas modernas de análise, a química destes compostos não está ainda muito bem compreendida. 
<smiles>[R]c1cc(-c2[o+]c3cc(O)cc(O)c3cc2O)cc(P)c1O</smiles>

$\mathrm{R}=\mathrm{R}^{\prime}=\mathrm{H}$ $\mathrm{R}=\mathrm{H}, \mathrm{R}^{\prime}=\mathrm{OH}$ $\mathrm{R}=\mathrm{R}^{\prime}=\mathrm{OH}$ $\mathrm{R}=\mathrm{H}, \mathrm{R}^{\prime}=\mathrm{OCH}_{3}$ $\mathrm{R}=\mathrm{OH}, \mathrm{R}^{\prime}=\mathrm{OCH}_{3}$ $\mathrm{R}=\mathrm{R}^{\prime}=\mathrm{OCH}_{3}$ pelargonidina cianidina delfinidina peonidina petunidina malvidina

Fig. 11 - As Antociadininas.

Os compostos fenólicos são geralmente divididos em quatro grupos: antocianinas, flavonas, ácidos fenólicos e taninos.

Antocianidinas e antocianinas

As antocianinas são glucósidos das antocianidinas (figs. 9 e 10 ). Estas últimas são compostos flavonóides (fig.12). Os flavonóides são o grupo mais extenso e diversificado das substâncias fenólicas.

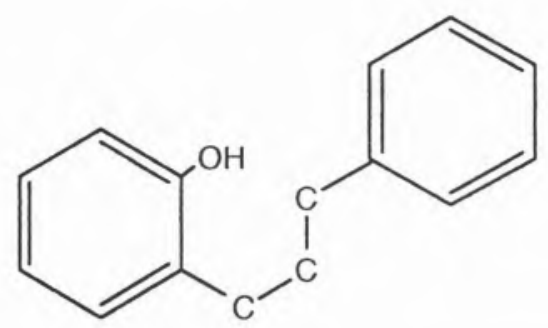

Fig. 12 - Estrutura flavonóide.

A designação flavonóide provém das flavonas (fig.13) por ser esta uma das formas mais comuns da estrutura flavonóide no mundo natural. São em geral solúveis na água e são, como se referiu, muitas vezes coloridas, sendo responsáveis pela maioria das cores das flores, frutos e folhas das plantas. Discutiremos, por isso, um pouco mais detalhadamente esta propriedade.

Tanto as flavonas como as antocianidinas (fig.11) são cromogénios, isto é, absorvem luz na região do visível através da excitação dos electrões dos seus grupos cromóforos (a região, na molécula, onde se dá essa absorção). São, além disso, de tipo dador-aceitador complexo. Isto significa que possuem grupos substituintes nos anéis A e B (ver fig.13) electrodadores (grupos $-\mathrm{OH}$ e $-\mathrm{OCH}_{3}$, geralmente) que, por efeito mesomérico, interactuam com o grupo electroaceitador que, neste caso, é o heteroátomo do anel central (ou um substituinte eventualmente presente, geralmente nas posições 3 ou 5 ).

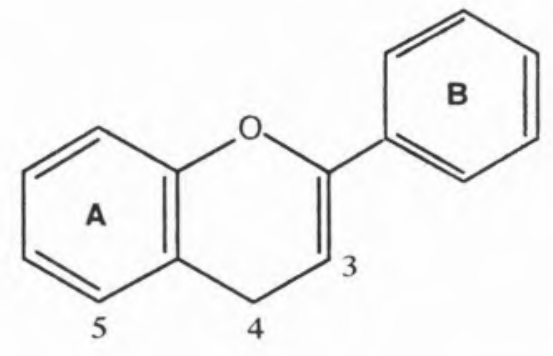

Fig. 13 - Flavona

Esta interacção faz-se através do sistema de ligações conjugadas dos aneis, mas o átomo de oxigénio no anel central pode também participar na conjugação, através do par de electrões n, não ligantes. Daí o nome de aceitador complexo dado a um cromóforo tal como este átomo de oxigénio, que contribui para o sistema conjugado, através do qual se realiza a interacção dador-aceitador, sendo ele, simultaneamente, o próprio aceitador. Como consequência deste fenómeno o hiato de energia entre os orbitais moleculares ligantes e antiligantes é reduzido, aumentando o comprimento de onda máximo de absorção. Assim, um composto que, de outro modo, absorveria no ultravioleta passa a absorver no visível, tornando-se colorido. Se o composto já era colorido, como é o caso de muitas antocianidinas e flavonas, muda de cor, na direcção do vermelho.

É, agora, evidente a razão pela qual a coloração das antocianidinas depende do $\mathrm{pH}$, visto que este interfere com o sistema dador-aceitador conjugado: em meio ácido forma-se um catião, por protonação, que é vermelho; no seu estado normal $(\mathrm{pH}$ 7), as antocianidinas são púrpura, e tornam-se azuis em meio alcalino, pela formação do anião. Esta característica permite que sejam usadas como indicadores.

É claro que, quando falamos das cores das antocianidinas, referimonos às cores observadas que não são, como se sabe, as cores da luz branca absorvida pela molécula, mas antes as cores complementares destas. Assim, quando o composto exibe a cor vermelha, ele absorve a 490-500 $\mathrm{nm}$ (verde azulado); quando é púrpura, absorve no verde a 500-560 nm e, quando é azul, absorve a 580$595 \mathrm{~nm}$ no amarelo.

Ao $\mathrm{pH}$ do vinho $(2,8-3,8) 20$ $25 \%$ das antocianinas são vermelhas (fig.14); é a estas que o vinho tinto novo deve a sua cor. O vinho branco, cuja fermentação se faz sem maceração das películas nem das partes sólidas dos cachos, não contém antocianinas nem flavonas ou a sua concentração é tão reduzida que é insuficiente para influir na cor do vinho.

De facto, não se sabe ainda muito bem o que é que dá a cor ao vinho branco, embora os compostos fenólicos a ela estejam, sem dúvida, associados. Sabe-se, por exemplo, que os complexos de $\mathrm{Fe}^{+}$com os ácidos orgânicos ou com compostos fenólicos possuindo dois grupos $\mathrm{OH}$ em posição orto são amarelos e estes estão certamente presentes no vinho branco influindo na sua cor final.

De notar ainda que, devido à localização das antocianinas na película da uva, com a excepção de algumas (poucas) castas, ditas tintureiras, 
<smiles></smiles>
$\mathrm{pH}=2$ vermelha<smiles>[R]C1=Cc2c(O)cc(O)cc2OC1=c1ccc(=C)cc1</smiles>

$\mathrm{pH}=7$<smiles>O=C1C=CC(=C2Oc3cc(O)cc(O)c3C=C2O)C=C1[O-]</smiles>

azul

Fig. 14 - A cor das antocianidinas depende do pH.<smiles></smiles>

forma oxidada<smiles>COc1cc(C2Oc3cc(O)cc(O)c3C=C2O)cc(O)c1O</smiles>

forma reduzida

Fig. 15 - As antocianidinas sofrem oxi-redução de forma reversível. A forma reduzida, mais abundante nos vinhos novos, é incolor.

em que elas também se encontram na polpa, pode obter-se sem qualquer dificuldade vinho branco a partir de uvas tintas, sendo a inversa impossível.

Como se viu, as antocianinas são heterósidos das antocianidinas. Assim, conquanto não se conheçam nos vinhos mais do que 50 antocianidinas, diferindo umas das outras nos grupos substituintes $\mathrm{R}$ e $\mathrm{R}^{\prime}$ (fig.11) e das quais a mais abundante é a malvidina, existem muito mais antocianinas, quer sejam monoglu- cósidos, diglucósidos ou derivados acilados destes.

A presença de diglucósidos é específica de algumas variedades de vinha ditas americanas, resistentes à filoxera e por isso usadas como porta-enxertos - vitis riparia e vitis rupestris. O carácter 'presença de diglucósidos' transmite-se, segundo as leis da genética, com o modo dominante. Assim, o cruzamento de vitis vinifera (vinha europeia) com vitis riparia ou vitis rupestris produz uma população de híbridos de primeira geração todos eles possuindo diglucósidos. O carácter recessivo - 'ausência de diglucósidos' - pode no entanto reaparecer, por exemplo em novo cruzamento de um híbrido de primeira geração com vinha europeia (vitis vinifera). A análise dos diglucósidos de um vinho tinto indica-nos, assim, se ele provém de vitis vinifera ou se é um produto híbrido.

As antocianidinas podem ainda influir na cor dos vinhos tintos, durante a conservação, de outras formas para além da já referida. Por um lado, elas reagem com o $\mathrm{SO}_{2}$ livre $\left(\mathrm{HSO}_{3}^{-}\right)$sempre presente nos vinhos, como conservante e anti-oxidante, desde o fim da fermentação. A reacção, provavelmente na posição 2 da molécula, dá origem a um composto incolor que está em equilíbrio com o sal do ião flavílio, descolorando, o vinho. À medida que o $\mathrm{SO}_{2}$ livre desaparece durante a conservação, o composto original é regenerado, e com este também a cor original.

Por outro lado, as antocianidinas polimerizam com os taninos ao longo do envelhecimento. Os polímeros que daí resultam já não são vermelhos mas sim acastanhados, tornando-se mais escuros à medida que a cadeia cresce, acabando por passar ao estado coloidal ou precipitar quando o peso molecular se torna muito grande. Isto, por um lado, descora o vinho e, por outro, contribui para o tom acastanhado próprio dos vinhos velhos.

Como se viu num dos exemplos anteriores, as antocianidinas sofrem oxidação-redução de forma reversível. Nos vinhos novos a concentra-

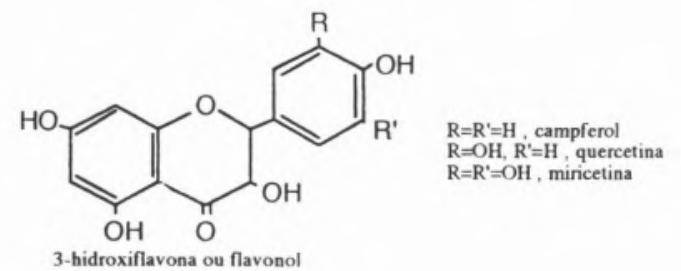

Fig. 16 - As flavonas não são, ao contrário do que se julgou por muito tempo, responsáveis pela cor do vinho branco. 


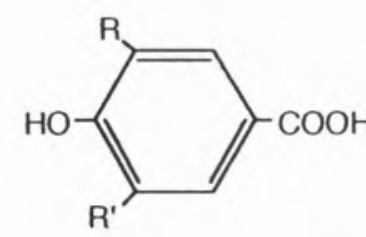

\begin{tabular}{|c|c|}
\hline $\begin{array}{l}\mathrm{R}=\mathrm{R}^{\prime}=\mathrm{H}, \\
\mathrm{R}=\mathrm{OH}, \mathrm{R}^{\prime}=\mathrm{H} \\
\mathrm{R}=\mathrm{OCH}_{3}, \mathrm{R}^{\prime}=\mathrm{H} \\
\mathrm{R}=\mathrm{R}^{\prime}=\mathrm{OH} \\
\mathrm{R}=\mathrm{R}^{\prime}=\mathrm{OCH}_{3}\end{array}$ & $\begin{array}{c}\text { ácido p-hidroxibenzóico) } \\
\text { " } \\
\text { " vrotocatecuico } \\
" \quad \text { gálico } \\
" \quad \text { siríngico }\end{array}$ \\
\hline $\begin{array}{l}\mathrm{R}^{\prime \prime}=\mathrm{H} \\
\mathrm{R}^{\prime \prime}=\mathrm{OH}\end{array}$ & $\begin{array}{l}\text { ácido salicílico } \\
\text { " gentísico }\end{array}$ \\
\hline
\end{tabular}

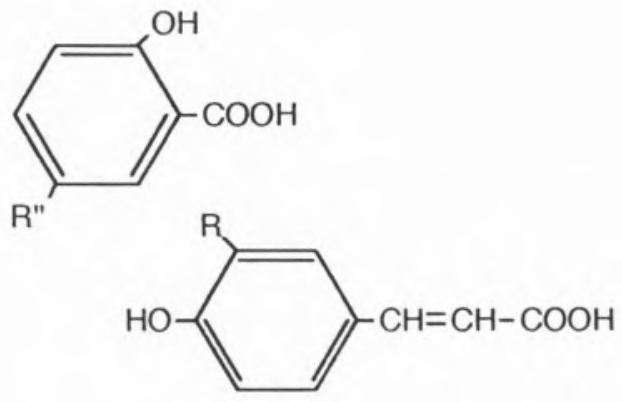

$\mathrm{R} "=\mathrm{OH} \quad$ "gentísico

$\left.\begin{array}{lcc}\mathrm{R}=\mathrm{H} & \multicolumn{2}{c}{\text { ácido } \text {-fumárico }} \\ \mathrm{R}=\mathrm{OH} & " & \text { cafeíco } \\ \mathrm{R}=\mathrm{OCH}_{3} & \text { ferúlico }\end{array}\right\}$ cinâmicos

Fig. 17 - Os ácidos benzóicos e cinâmicos do vinho.

ção da forma reduzida incolor (fig.15) será máxima, oxidando-se depois progressivamente pelo contacto directo com o oxigénio do ar, ou dissolvido no vinho sobretudo no decurso das trasfegas. Neste caso, o envelhecimento proporciona cor.

De qualquer modo, o resultado final destas reaç̧ões envolvendo as antocianidinas, em termos do seu contributo para a coloração do vinho, é o determinado pela polimerização: há um decréscimo de intensidade da coloração com a idade e a cor evolui desde o vermelho-rubi no vinho novo até ao castanho-avermelhado no vinho velho. Não são, no entanto, as antocianidinas as únicas responsáveis, nem sequer as principais, por esta coloração típica dos vinhos velhos mas sim, como veremos, os taninos.

\section{Flavonas}

As flavonas são compostos flavonóides (figs.12 e 13) existentes nas flores e nos frutos como pigmentos amarelos. Existem no bago das uvas tintas como monoglucósidos (grupo $\mathrm{OH}$ na posição 3) dos flavonóis campferol, quercetina e miricetina (fig.16) e como monoglucósidos da quercetina. Não são, no entanto e ao contrário do que se pensou por muito tempo, os responsáveis pela cor do vinho branco.
Estes heterósidos hidrolisam facilmente e em consequência encontram-se nos vinhos tintos as agliconas livres dos três compostos mencionados (algumas dezenas de mg/l). Nos vinhos brancos, em que a maceração pelicular está em geral ausente, apenas se encontram vestígios.

\section{Ácidos fenólicos}

A uva e o vinho contêm sete ácidos benzóicos e três ácidos cinâmicos (fig.17) diversamente hidroxilados e metoxilados, variando as suas concentrações de 0,1 a $30 \mathrm{mg} / \mathrm{l}$. Encontram-se no estado livre ou esterificados pelo ácido tartárico. São responsáveis pelo escurecimento do mosto por oxidação enzimática (polifenoloxidase da uva e do fungo botrytis cinerea). No que respeita aos derivados cinâmicos, predomina a forma trans por ser mais estável.

A este grupo de compostos fenólicos pode acrescentar-se o tirosol cuja origem, ao contrário dos anteriores, não está na uva mas sim na fermentação, visto ser um produto desta, formado pelas leveduras a partir do amino-ácido correspondente, a tirosina. É por isso que, enquanto os primeiros quase não existem nos vinhos brancos, este último existe em geral em iguais quantidades nos vinhos brancos ou tintos.

\section{Taninos}

Os taninos são, com as antocianinas, os compostos fenólicos que mais influenciam as características do vinho, em especial do vinho tinto. De facto, enquanto o teor em tanino no vinho branco é da ordem das dezenas de mg/l, no vinho tinto essas quantidades sobem para níveis entre 1 e $3 \mathrm{~g} / \mathrm{l}$, cerca de cem vezes mais. Isto fica a dever-se à sua localização na película, graínhas e sobretudo nos engaços dos cachos: só na vinificação em tinto é que a extracção dos produtos dessas partes das uvas e do cacho é significativa; na vinificação em branco, geralmente de bica aberta, o contacto entre o mosto e as partes sólidas da vindima é reduzido ao mínimo.

Os taninos resultam da polimerização de compostos fenólicos elementares, tendo por isso elevado peso molecular, de 600 a 5000 . Divi-
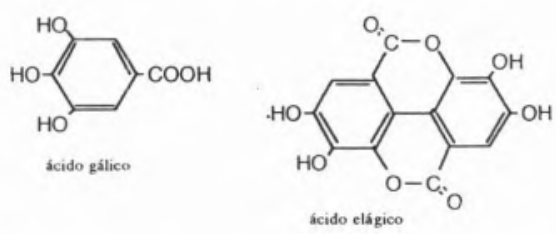

Fig. 18 - A estrutura dos taninos hidrolisáveis deriva dos ácidos gálico e elágico. 


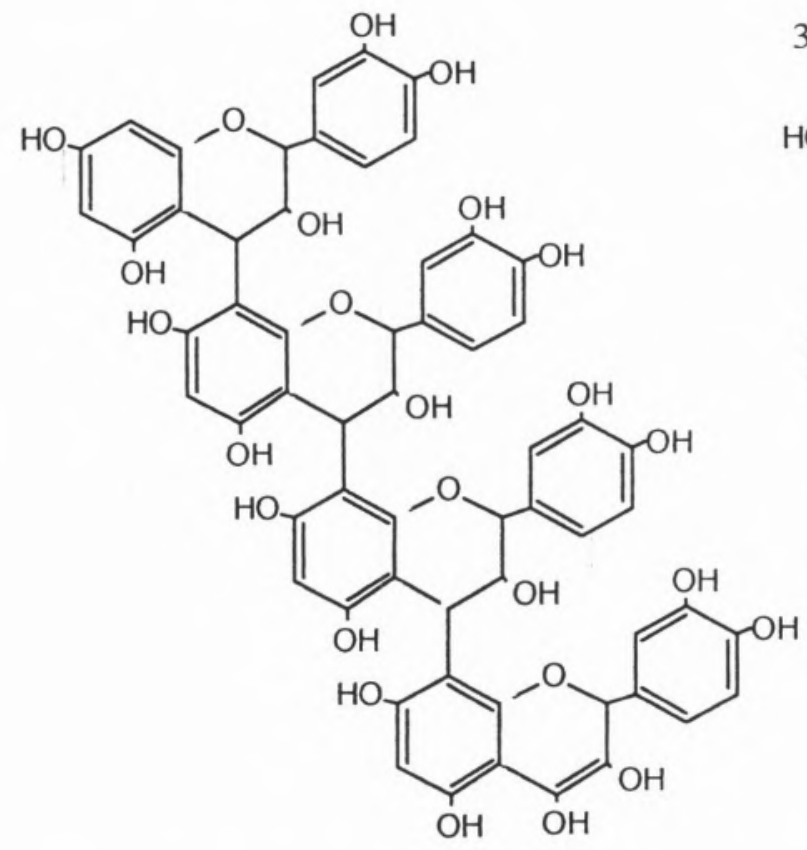<smiles>[R]c1ccc([C@@]2(C)Oc3cc(O)cc(O)c3C[C@H]2O)cc1O</smiles>

$$
\begin{array}{ll}
\mathrm{R}=\mathrm{OH}, \mathrm{R}^{\prime}=\mathrm{H} & \text { catequina } \\
\mathrm{R}=\mathrm{R}^{\prime}=\mathrm{OH} & \text { galocatequina }
\end{array}
$$<smiles>Oc1cc(O)c2c(c1)OC(c1ccc(O)c(P)c1)C(O)C2</smiles>

$\mathrm{R}=\mathrm{OH}, \mathrm{R}^{\prime}=\mathrm{H} \quad$ leucocianidina $\mathrm{R}=\mathrm{R}^{\prime}=\mathrm{OH} \quad$ leucodelfinidina

dem-se em hidrolisáveis e não hidrolisáveis ou pirocatéquicos (ou de condensação). São estes últimos que existem na uva e na vinha. No entanto são os primeiros que se encontram geralmente no comércio, sendo a sua adição ao vinho legal, embora sem vantagens na maioria dos casos. A sua estrutura é derivada do ácido gálico ou da lactona do seu dímero, o ácido elágico (fig.18).

Estas moléculas estão unidas por ligações glucídicas com a glucose ou com os seus poliósidos (glucosanas) derivados.

Ao contrário dos anteriores, os taninos da uva e do vinho são compostos de estrutura flavanóide polimerizada (fig.19). Mais exactamente são polímeros de 3-flavanol-catequinas e, sobretudo, de 3,4-flavanedióis, as leucoantocianidinas. Estas ultimas dão, por aquecimento em meio ácido na presença de ar, as antocianidinas, de que já falámos. Esta reacção não tem, no entanto, significado do ponto de vista biológico, não devendo os taninos ser considerados como derivados das antociani- dinas, considerando-se a reacção apenas característica na análise para detecção das leucoantocianidinas (fig.20).

Os taninos são muito reactivos com as proteínas, formando compostos de elevado peso molecular, que precipitam. Essa característica é determinante no papel que os taninos desempenham no vinho: por um lado eles facilitam a clarificação espontânea ou por colagem com proteínas (albuminas, sangue de boi, etc.); por outro conferem aos vinhos que os contêm em abundância o seu sabor adstringente tão característico. Neste último caso, são as proteínas e glicoproteínas da saliva que precipitam com os taninos, deixando de cumprir o seu papel de lubrificantes da cavidade bucal, daí resultando adstringência. É ainda esta característica que faz dos taninos inibidores enzimáticos, por combinação com a fracção proteica dos enzimas.

O grau de polimerização dos taninos no vinho aumenta com a idade. No entanto a estrutura desses polímeros não é ainda bem conhecida. Sabe-se que o seu peso molecular aumenta de entre 500800 , nos vinhos novos, até aos 3000-4000 nos vinhos velhos. É

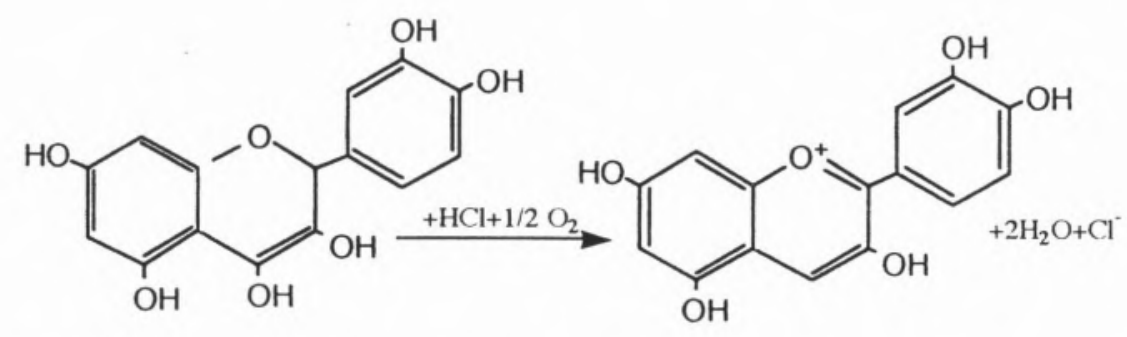

Fig. 20 - Reaç̧ão característica das leucoantocianidinas. flavanediol. 
também possível que as antocianidinas participem na polimerização através de ligações em C-4 do anel central, originando um polímero misto com os taninos. Isto explicaria também o facto bem conhecido do desaparecimento gradual das antocianidinas ao longo do tempo durante o envelhecimento.

Em todo o caso sabe-se que é aos taninos polimerizados que se deve a cor nos vinhos velhos e não já às antocianidinas (ver secção sobre a cor). Na hipótese da condensação mista a estrutura da antocianidina continuaria a contribuir para a coloração do vinho, embora dentro do tanino condensado.

\subsection{As substâncias da nutrição}

Os diversos grupos de que temos falado até aqui são os que determinam o paladar. Falaremos a seguir de outros que, embora não influindo neste - pelo menos em condições normais de conservação têm, no entanto, influência na qualidade do produto final (estabilização, qualidade alimentar).

Estão neste caso os compostos azotados. Em geral, o enólogo deseja que eles não estejam presentes no vinho acabado, ou quanto menos melhor. Isto porque eles são um factor de risco na conservação, devido à instabilidade microbiológica que trazem consigo porque possibilitam o metabolismo de leveduras e microorganismos, sempre presentes no vinho feito. A esterilização, para além dos problemas técnicos $\mathrm{e}$ de custo que levanta, não se pode fazer sem prejuízo irrecuperável das qualidades organolépticas do vinho.

O grupo dos compostos azotados é constituído pelo catião amónio $\left(\mathrm{NH}_{4}^{+}\right)$e pelos compostos orgânicos contendo átomos de nitrogénio: aminoácidos, péptidos e proteínas; aminas primárias, secundárias e terciárias; derivados aminados das hexoses, as hexosaminas; nucleósidos e nucleótidos.

O teor em compostos azotados no mosto é muito superior ao que depois se encontra no vinho. Isso

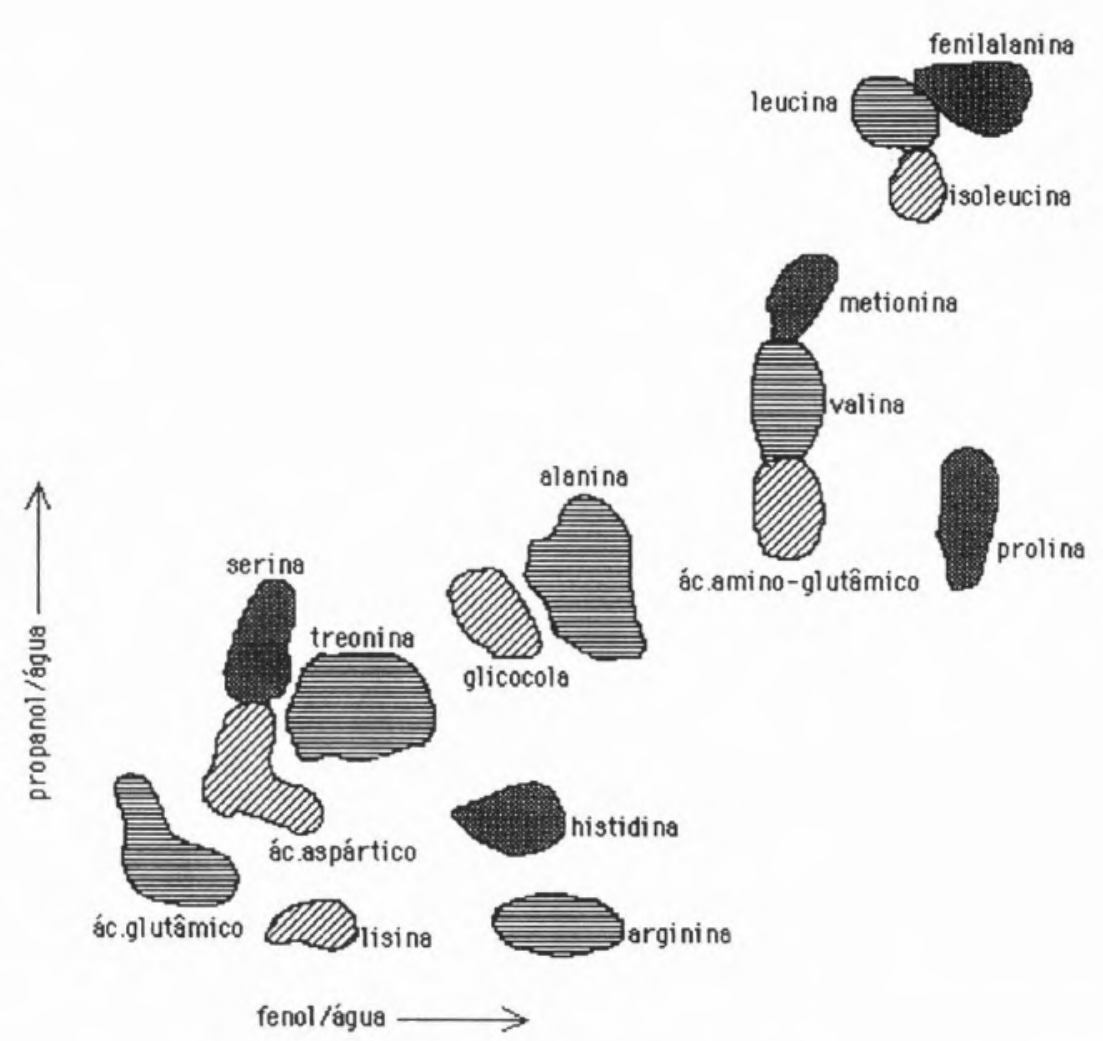

Fig. 21 - Cromatograma em papel, a duas dimensões, dos aminoácidos no vinho.

não é de admirar visto que as leveduras consomem durtante a fermentação entre 60 e $70 \%$ do azoto total do mosto.

Nos vinhos tintos a quantidade de compostos de nitrogénio é maior do que nos brancos devido à diferença das técnicas de vinificação. A maceração das películas e dos engaços, nos primeiros, conduz a uma grande dissolução dos compostos azotados, que aí abundam, no mosto. Nos segundos, a separação imediata do sumo das partes sólidas

Quadro 1 - As vitaminas do vinho

\begin{tabular}{lll}
\hline nome do composto & nome da vitamina & concentração \\
\hline ácido ascórbico & $\mathrm{C}$ & $3-10 \mathrm{mg} / \mathrm{l}$ \\
ácido fólico & $\mathrm{B}_{9}$ & $1-20 \mathrm{~g} / \mathrm{l}$ \\
ácido pantoténico & $\mathrm{B}_{5}$ & $0,2-1,8 \mathrm{mg} / \mathrm{l}$ \\
biotina & $\mathrm{B}_{8}$ ou H & $0,5-2,5 \mathrm{~g} / \mathrm{l}$ \\
cobalamina & $\mathrm{B}_{12}$ & $20-70 \mathrm{mg} / \mathrm{l}$ \\
inositol & - & $0,2-0,7 \mathrm{mg} / \mathrm{l}$ \\
nicotinamida & $\mathrm{B}_{3}$ ou PP & $0,4-2,0 \mathrm{mg} / \mathrm{l}$ \\
riboflavina & $\mathrm{B}_{2}$ & $0,1-0,5 \mathrm{mg} / \mathrm{l}$ \\
tiamina & $\mathrm{B}_{1}$ & $10-250 \mathrm{~g} / \mathrm{l}$ \\
\hline
\end{tabular}

do cacho, impede essa dissolução. Apenas contêm os compostos originários da polpa da uva que são sobretudo aminoácidos e péptidos e o catião amónio.

O catião amónio diminui de concentração no bago de uva ao longo da maturação, enquanto crescem os aminoácidos em número e em quantidade. A L-prolina é o mais abundante. É também dos mais abundantes no vinho feito por ser pouco metabolizável pelas leveduras. Estas produzem, ainda, du- 
rante a fermentação, ácido L-glutâmico e algumas proteínas. No entanto o consumo que as leveduras fazem de compostos azotados é muito maior do que a quantidade que produzem e, daí, o teor final destes compostos no vinho ser baixo. Também os taninos ajudam à precipitação das proteínas e quase todos os tratamentos realizados na adega promovem essa precipitação.

Do grupo das substâncias da nutrição fazem ainda parte os polissacáridos e as vitaminas.

Os polissacáridos mais abundantes $(0,1-3,0 \mathrm{~g} / \mathrm{l})$ no vinho provêm das paredes celulares da uva. São pectinas e protopectinas. Estas substâncias agem como colóides protectores influenciando os processos de clarificação.

As vitaminas que se encontram no vinho são as hidrossolúveis. $\mathrm{O}$ elevado teor em vitaminas na uva diminui durante a fermentação onde têm um papel importante no desenvolvimento das leveduras.

O quadro 2 mostra uma lista das vitaminas bem como das concentrações em que se encontram no vinho.

\subsection{As substâncias do aroma}

O aroma, ou seja, o conjunto das sensações que o vinho nos transmite através do olfacto, constitui uma das suas propriedades mais importantes do ponto de vista organoléptico. De facto, a riqueza das sensações que o vinho comunica na prova está estreitamente ligada ao aroma: as substâncias voláteis que o vinho liberta percorrem a boca até atingirem os receptáculos olfactivos da mucosa nasal, onde os sentimos como aromas.

As sensações que o vinho desencadeia na boca do provador são, assim, induzidas não apenas pelos sabores identificados nas diferentes partes da língua, mas resultam do conjunto sabores+aromas. Costuma exemplificar-se este facto provando um vinho de nariz fechado, ou seja, impedindo a circulação de ar pelos canais nasais e limitando assim a chegada dos compostos voláteis aos

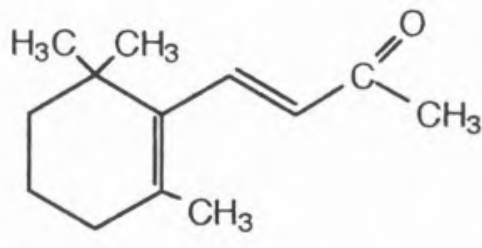

ß-ionona<smiles>COc1nccnc1C(C)C</smiles>

2-metoxi-3-isobutil-pirazina

Fig. 21 - Algumas moléculas com importância no aroma do vinho.

receptáculos do aroma. A sensação que o vinho, por melhor que seja, causa nestas condições é sempre muito pobre e inesperadamente diferente da prova normal.

De notar que, evidentemente, nem todos os compostos voláteis têm aroma. A maioria não tem. No entanto, todos são vectores do aroma na medida em que quanto maior for a sua concentração na fase líquida, maior será a pressão de vapor do vinho e, portanto, maior será a frequência de chegada dos compostos específicos do aroma aos receptáculos nasais do olfacto.

Por outro lado, a intensidade de um aroma não depende apenas da concentração do composto químico correspondente na fase líquida. O nosso sentido olfactivo parece ser bastante mais sensível a certos cheiros do que a outros.

De qualquer forma, o mecanismo do cheiro não está ainda hoje muito bem esclarecido e, com respeito aos vinhos, a correspondência entre cada aroma e o composto que o origina está longe de ser completamente desvendada, conhecendo-se apenas essa relação em muito poucos casos.

Parece também ser um facto que algumas substâncias podem produzir aromas diferentes consoante a sua concentração em fase de vapor. A mistura de vários aromas pode, ainda, resultar num novo aroma sem relação com nenhum dos aromas presentes. Tudo isto não faz senão dificultar ainda mais o estudo do assunto.

Dos compostos cuja identificação do aroma está feita tem importância o aroma das castas moscatéis que é originário nos compostos terpénicos (geraniol, nerol, a-terpiniol, limoneno, linalol, citronelol, farnesol) (fig.22). Em Portugal, onde as castas deste grupo são numerosas, o estudo destes compostos tanto na uva como no vinho tem sido seguido com interesse e, em particular, na Região dos Vinhos Verdes esse estudo tem incidido sobre a casta Loureiro, que é o membro regional dessa família de castas aromáticas.

Uma classificação clássica dos aromas do vinho consiste em dividilos de acordo com a etapa da vinificação em que se formam: fermentário, pré-fermentário e post-fermentário, se se formam respectivamente durante, antes ou depois da fermen-
Quadro 2 - Alguns compostos odoríferos, sua concentração no vinho e limiar de detecção pelo olfacto humano.

\begin{tabular}{lccc}
\hline $\begin{array}{c}\text { Composto } \\
\text { em água }\end{array}$ & $\begin{array}{c}\text { Concentração mínima detectável } \\
\text { pelo olfacto em } \boldsymbol{\mu g} / \mathbf{l} \\
\text { em vinho }\end{array}$ & $\begin{array}{c}\text { Concentração no } \\
\text { vinho em } \boldsymbol{\mu g} / \mathbf{l}\end{array}$ \\
\hline etanol & 105 & - & $9 \times 107$ a $14 \times 107$ \\
$\beta$-damascenona & 10 & 1600 & 5 a 50 \\
$\beta$-ionona & 0,007 & 4,5 & 1 a 30 \\
$\begin{array}{l}\text { 2-metoxi-3-isobutil } \\
\text { pirazina }\end{array}$ & 0,002 & $?$ & vestígios \\
\hline
\end{tabular}


tação. Chama-se ainda aroma varietal ao que é específico da casta (como no caso do Loureiro, referido acima).

\section{Aroma fermentário}

A fermentação é a maior fonte de compostos voláteis do vinho e o aroma que daí resulta é, de certo ções que variam entre os 2 e os 30 $\mathrm{mg} / \mathrm{l}$.

Os outros produtos voláteis com origem na fermentação existem em concentrações inferiores, com excepção dos que constam na tabela acima, e em especial o acetaldeído cuja concentração pode ir de 10 a mais de $100 \mathrm{mg} / \mathrm{l}$.

Quadro 3 - Os principais compostos voláteis do vinho.

\begin{tabular}{llll}
\hline Alcoóis & \multicolumn{2}{c}{ Ésteres } & Outros \\
\hline etanol & acetato de etilo & acetato de 2-feniletilo & acetaldeído \\
álcool isoamílico & acetato de isoamilo & lactato de etilo & acetoína \\
2-feniletanol & octanoato de etilo & succinato de etilo & diacetilo \\
isobutanol & hexanoato de etilo & 4-hidroxibutanoato & $\gamma$-butirolactona \\
de etilo & malato de etilo & ácidos gordos \\
propanol & propanoato de etilo & & \\
1-butanol & rutanoato de etilo & & \\
3-metiltiopropanol & & & \\
\hline
\end{tabular}

modo, a base aromática comum a todos os vinhos.

As leveduras formam variadíssimos compostos voláteis (quadro 3); a maioria são alcoóis e ésteres. Além do etanol, formam-se também alcoóis isoamíllicos, 2-feniletanol, isobutanol, propanol, 2-butanol, 1butanol, 3-metiltiopropanol, em concentrações que variam entre os 0,15 e $0,5 \mathrm{~g} / \mathrm{l}$, com excepção do último que existe apenas entre 0,5 e 2 $\mathrm{mg} / \mathrm{l}$.

Quanto aos ésteres, os mais abundantes são os que resultam da esterificação dos ácidos do vinho pelo etanol. Existem em concentra-

\section{Aroma pré-fermentário}

Provém em grande parte de compostos de cadeia em C-6 (hexanol, cis e trans-hexanol e álcoois correspondentes). Formam-se a partir dos ácidos linoleico e linolénico existentes na uva, sob a acção de enzimas, na presença do ar (fig.21). Os aromas daí resultantes são herbáceos e de má qualidade.

É nesta fase que os heterósidos de terpinóis das castas aromáticas são hidrolisados libertando as agliconas terpénicas. As pectinas (poliósidos da galacturose) também, por acção enzimática, libertam metanol. Este fenómeno não é específico da uva e do vinho, mas é comum a todos os sumos de frutos e seus produtos de fermentação.

\section{Aroma varietal}

É o aroma específico da casta. Já nos referimos à importância que os compostos terpénicos têm no aroma das variedades moscateis. Eles têm sido encontrados, além disso, em todas as castas aromáticas. Estes compostos podem surgir, no entanto, de duas maneiras: em parte existem já na uva como substâncias odoríferas (geraniol, nerol, linalol,...); noutra parte, são libertados, como também vimos, durante a fermentação dos heterósidos terpénicos. Neste caso chamam-se substâncias odorígenas ou precursoras de aroma.

Ao grupo dos odoríferos pertencem também algumas pirazinas nas quais se inclui a 2-metoxi-3-isobutilpirazina, aroma intenso que existe, por exemplo, na bem conhecida casta bordalesa Cabernet-Sauvignon. Este composto degrada-se, no entanto, rapidamente com a luz durante a maturação, restando apenas uma pequena quantidade na uva no momento da vindima.

Os ésteres etílico e metílico do ácido antranílico são, por sua vez, associados às furanonas, os responsáveis pelo cheiro característico do vinho americano.

Recentemente, crê-se que uma grande variedade de aromas identificados no vinho de longa data (mel, violetas, petróleo, fumo, etc.) resultam de substâncias carotenói-

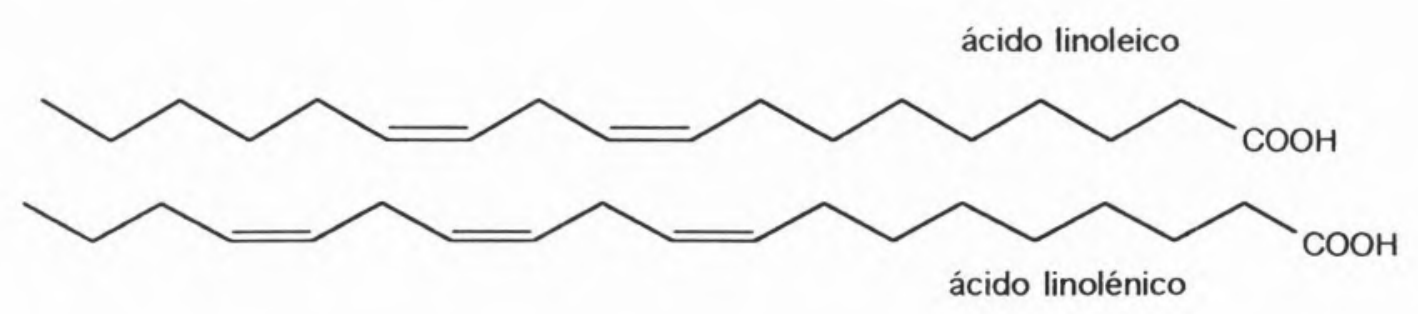

Fig. 22 - Ácidos cis,cis-9,12-octadecadienoico (linoleico) e cis,cis,cis-9,12,15-octadecatrienoico (linolénico). Ambos são precursores dos aromas pré-fermentários, herbáceos e de má qualidade. 

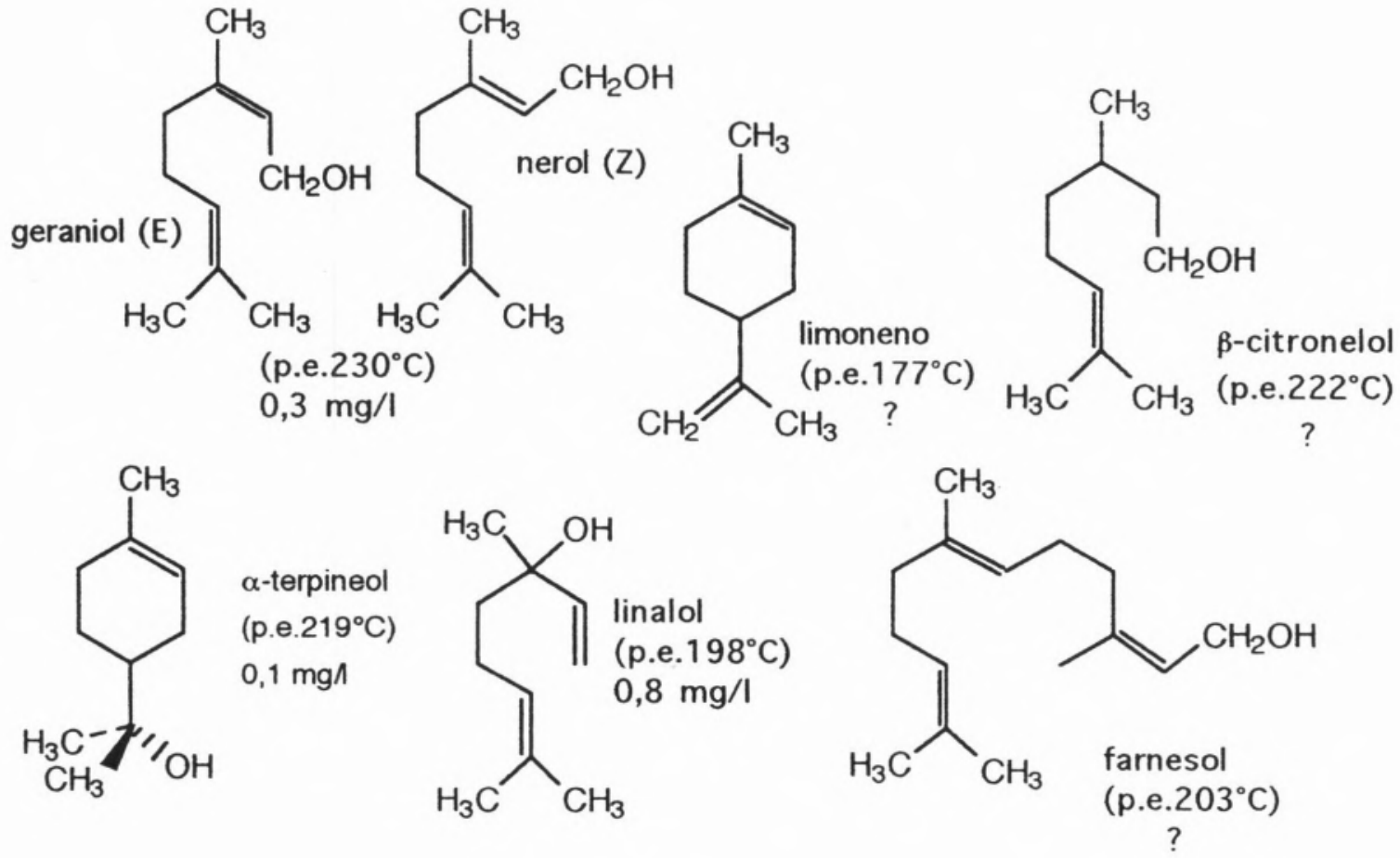

Fig. 23 - O aroma varietal das castas moscatéis tem origem nos compostos terpénicos.

des (carotenos e xantofilas) e de ácidos fenólicos. Os carotenos, presentes em doses que podem ir de 1 a $2 \mathrm{mg} / \mathrm{l}$ no mosto, são pelo menos, importantes percursores de aroma. Quer dizer, embora eles próprios não sejam possuidores de aroma vão no entanto sofrer reacções, frequentemente catalisadas por enzimas ou pela luz, em que se degradam e os terpenóides daí resultantes são já aromáticos.

A época em que se atribuía o aroma dos vinhos a um suposto “éter enântico" já vai longe. Falta, no entanto, ainda mais algum tempo para se chegar à compreensão total do aroma e à identificação e localização dos compostos que lhe são próprios, nas uvas das diferentes castas, nas fermentações e no vinho.

\footnotetext{
* Universidade do Minho

Guimarães
}

\section{NOTAS}

** perceptivel sensorialmente pelo provador.

1 Enologia: conjunto das ciências e técnicas ligadas à produção, análise e melhoramento do vinho.

2 São quatro essas características: aroma, boca (paladar), cor e brilho.

${ }^{3} \mathrm{Na}$ Alemanha, por exemplo.

${ }^{4}$ Vinhos secos são aqueles cujo teor em açúcar não fermentado não exceda os $3 \mathrm{~g} /$.

5 As constantes de ionização do ácido málico são $\mathrm{K}_{\mathrm{a} 1}=$ $4,0.10^{-4}, K_{a 2}=8,9.10^{-6}$ contra $K_{a}=1,410^{-4}$.

${ }^{6}$ Durante muito tempo, o vinho foi considerado apenas uma solução de álcool em água.

7 Entende-se por sulfitação, em enologia, a adição de dióxido de enxofre ao mosto ou ao vinho e constitui uma prática tão comum quanto sensível, se feita racionalmente.

${ }^{8}$ Sigla correspondente à designação oficial de Denominação de Origem Controlada.

9 Com excepção do ácido múcico, que aparece quando as vindimas vêm atacadas de botrytis cinera (podridão).

\section{BIBLIOGRAFIA}

R.Baumes, "Six cents corps pour un bouquet", Science et Vie, $n^{\circ} 156$ (hors série), Setembro, 1986, pág.90.

L. Campos, "Manual de Bioquímica", Biblioteca Universitária, Pub.Europa-América, Lisboa.

T.P. Coultate, "Food-The Chemistry of its Components", The Royal Society of Chemistry, London, 1984.

P. Karlson, "Manual de Bioquímica", Ed.Marin S/A, Barcelona, 1969.

L.H.Meyer, "Food Chemistry", The Avi Publishing Company, Inc., Westport Connecticut, 4th ed., 1982.

R. Morrison, R.Boyd, "Química Orgânica", Fundação Calouste Gulbenkian, Lisboa, $7^{\circledR}$ ed., 1981.

E. Peynaud, "Conhecer e trabalhar o vinho", Livros Técnicos e Científicos Lda., Lisboa, 1982.

J. Ribéreau-Gayon, E.Peynaud, P.Sudraud, P.RibéreauGayon, "Traité d'CEnologie", Tomes I, II et III, Dunod, Paris 1975, 1976.

C. Ricardo, A.Teixeira, "Moléculas biológicas", Didáctica Editora, Lisboa, 1977. 